\title{
Jochen Pagenberg 80
}

\section{Alexander von Mühlendahl}

The petition presented recently to the U.S. Supreme Court for the grant of certiorari in the case Amarin Pharma, Inc. v. Hikma Pharmaceuticals USA Inc., on appeal from the Court of Appeal for the Federal Circuit, reads as follows:

In Graham v. John Deere Co. of Kansas City, 383 U.S. 1 (1966), this Court established four factors that a court must consider in determining whether a patent is obvious and therefore unpatentable under 35 U.S.C. $\S 103$. Three of those factors relate to technical differences between the invention and the prior art. The fourth factor concerns objective facts indicating that the field of art did not treat the claimed invention as obvious. These objective indicia include long-felt but unresolved needs ultimately addressed by the invention, failure of others to make the invention, and commercial success of products embodying the invention. This Court has made clear that objective indicia must be considered along with the other factors before concluding that any invention is obvious, so that real world indicators - which are often the strongest evidence of nonobviousness - may guard against the risk that patents will incorrectly appear obvious in hindsight.

The Federal Circuit has improperly relegated objective indicia of nonobviousness to a secondary role. Under the Federal Circuit's framework, a court first considers only the three technical Graham factors and reaches a conclusion of "prima facie" obviousness. Only then does the court consider objective indicia, merely as a basis for rebutting a conclusion already reached. The result is over-invalidation of patents through hindsight bias and the suppression of innovation. 
The question presented is: Whether a court must consider objective indicia of nonobviousness together with the other factors bearing on an obviousness challenge before making any obviousness determination.

What does Jochen Pagenberg's 80th birthday have to do with this petition? For those of us who have followed Jochen's progress throughout the past 50 years or more, the context is obvious: Jochen, having completed his law studies in Munich in 1968, became a staff member of the Max Planck Institute for Foreign and International Patent, Copyright and Competition Law (after multiple name changes now the Max Planck Institute for Innovation and Competition), then under the direction of professors Eugen Ulmer, Friedrich-Karl Beier and later Gerhard Schricker. After the second state examination in 1972, he studied for a year at Harvard, obtained an LL.M., and became enamored with U.S. patent law, and in particular the notion of obviousness. Upon his return from the States, he completed, in 1974, his "Doktorarbeit", which was published in 1975 as vol. 36 in the series "Schriftenreihe für gewerblichen Rechtsschutz" published by the Max Planck Institute, with the title "Die Bedeutung der Erfindungshöhe im amerikanischen und deutschen Patentrecht". The recent reference in the Amarin case shows that the so-called "Beweisanzeichen" for non-obviousness (now: inventive activity since the adoption of the European Patent Convention in 1973) are as relevant today as they were then. These were the true "high point" years of the Max Planck Institute's exploration of the world of intellectual property law - and patent law specifically - as exemplified by Jochen's dissertation and those of many of his friends and colleagues, such as Gottfried Strohm, Uwe Dreiss, Bernhard Geissler, Reinhard Wieczorek, Dieter Stauder, Gert Kolle, Paul Ströbele and Rudolf Teschemacher. Others covered copyright law, trademark law, unfair competition law, design law, with the Institute extending its reach to Eastern European countries and Japan, with then still young researchers and practitioners from the United States (Warren Grimes, Harold Wegner, Peter Nikolai, Richard Schwaab come to mind) joining the ambitious activities of the Institute.

Most of us left the Institute in the course of the 1970s or 1980s, some of us joining the European Patent Office (Gert Kolle, Dieter Stauder), others the German Patent Office (Paul Ströbele, Rudolf Teschemacher who later became a chairman of one of the Boards of Appeal at the EPO), still others becoming members of the bar in Munich and elsewhere, or went abroad (Bernhard Geissler), while I became an official at the German Ministry of Justice. Jochen Pagenberg stayed in Munich, and joined, in 1979, patent attorneys Wolfgang Dost and Udo Altenburg to establish a pioneering law firm composed of patent attorneys and lawyers. Bernhard Geissler came on board later, and the firm, after some changes, was then called "Bardehle Pagenberg Dost Altenburg Geissler". The original founders have by now all retired, but the firm still carries his name, as BARDEHLE PAGENBERG.

Jochen Pagenberg also established the firm's Paris office, having previously worked in the law firm of Paul Mathely, and had important French clients, such as L'Oréal and the creators of Asterix and Obelix. Jochen Pagenberg was also the trademark law expert of the firm and became a successful litigator in this field as well, notably representing McDonald's with its successful efforts to establish the brand as a "famous" trademark. I remember very well two cases where the 
defendants raised the so-called "Euro" defense (claiming that the application of national law - in both cases German unfair competition law - would amount to an infringement of what was then Art. 30 of the EEC Treaty safeguarding the free movement of goods) and convinced the first instance court, the Landgericht München I, to refer questions to the Court of Justice of the European Union. In the first case, Th. Kohl KG v. Ringelhan \& Rennett SA, Case 177/83, Jochen Pagenberg, representing the defendant, prevailed with the "Euro" defense. In the second case, Pall Corp. v. P.J. Dahlhausen \& Co., Case C-238/89, Jochen Pagenberg was representing the plaintiff and "lost" because of the successful "Euro" defense. I recall these cases because during my time at the German Ministry of Justice I was, with others, responsible for defending the application of German unfair competition law in the cases before the CJEU, and actually argued the Pall case in the hearing in July 1990 in support of the case presented by Jochen Pagenberg.

In later years, Jochen Pagenberg became one of the principal promoters of creating a unified European patent court system: from 2000 until 2005 as an expert of the European Working Group for the European Patent Litigation Agreement (EPLA), from 2008 to 2011 as a member of the Expert Group of the European Commission and, simultaneously, between 2005 and 2011 as a board member, Vice President and President of the European Patent Lawyers Association (EPLAW). He was also the Chairman of the Special Committee of the AIPPI for an Agreement on the European Patent Court. One of his most significant achievements surely is the creation of the Venice Conferences bringing together patent judges from across Europe with lawyers, creating an informal forum for the exchange of information, experiences and practices. These Venice Conferences, under aegis of EPLAW, were unique settings for an informal "harmonization" of patent law, unfortunately without the envisaged EPLA becoming a reality. Hopes were high at the time that the EPLA would obviate the need to create a patent litigation system for the EU Member States alone. Instead, we are currently still looking at the unfinished Unified Patent Court Agreement, an endeavor which Jochen Pagenberg has accompanied with undiminished skepticism, as witnessed in many articles he has written on the subject. Among his many merits is the induction into the IP Hall of Fame, joining his partner Heinz Bardehle and also Friedrich-Karl Beier.

Jochen Pagenberg has maintained links with the academic world throughout his career, both as a teacher in many venues, but also as an author. And, of course, as the managing editor and co-editor of this journal, IIC.

Now, on the occasion of his 80th birthday, Jochen Pagenberg can look back on a truly fulfilled professional life, and can look forward to hopefully many more years at his domicile on the Tegernsee, but also in South Africa, from where he was able to catch the last flight to Europe when the coronavirus pandemic brought everything to a standstill.

Ad multos annos!

Publisher's Note Springer Nature remains neutral with regard to jurisdictional claims in published maps and institutional affiliations. 